\title{
Eufrosina regressa à escola
}

\author{
SILVINA PEREIRA \\ CEC-FLUL / Teatro Maizum \\ silvinapereira@netcabo.pt
}

Tras a nevoa vem o sol / Tras um tempo vem outro tempo

Jorge Ferreira de Vasconcelos

\section{Prólogo}

Aqui se falará da tradição de representações dramáticas nas Universidades, nomeadamente na Universidade de Coimbra, "divertimentos escolares" em que participavam alunos e lentes. Um costume relacionado com a vida académica, proporcionando um saber prático sobre matérias como o Latim ou a Retórica, assim como a aplicação de um processo de aprendizagem assente nas técnicas de memorização. Pretende-se ainda reflectir sobre a presença contemporânea dos clássicos na escola e o reatar de uma tradição através da representação de uma versão juvenil da Comedia Eufrosina de Jorge Ferreira de Vasconcelos.

\section{Acto}

As Universidades eram pólos de cultura clássica, onde se estudavam os mais admiráveis modelos da antiguidade greco-latina, entre os quais, Terêncio, Séneca e Plauto. No fervor renascentista salmantino viveram autores como Juan del Encina, ou Fernando de Rojas e, neste ambiente universitário, foram criadas obras dramáticas que viriam mais tarde a respirar o ar das praças públicas e dos primeiros currais de comédias, enquanto o chamado drama humanístico se desenvolvia em círculos mais restritos. Francisco López Villalobos (1473-1549), com Amphitruo de Plauto, e Fernán Pérez de Oliva (1494-1533) que, depois de ter refundido a obra plautina, traduziu livremente a Electra de Sófocles com o título de La venganza de Agamenón e a Hécuba triste de Eurípides, são alguns exemplos. Algumas traduções seriam destinadas à leitura mas, outras, tinham como fim a representação. Segundo Justo Soriano:

A las traducciones siguieron inmediatamente las imitaciones en latim. Tomando por modelo a Plauto, el erasmista salmantino Juan de Maldonado compuso una comedia titulada Hespaniola, em prosa latina, que debió de ser un ejercicio 
escolar hecho hacia el año 1519, aunque después mereciera el honor de ser representada en Portugal, en la corte de doña Leonor, reina de Francia, y luego tambiém con grande aplauso en Burgos. ${ }^{1}$

Outro exemplo sugestivo é oferecido pelo humanista e poeta toledano, Juan Pérez, conhecido por Petreius (1512-1545), catedrático de Retórica em Alcalá de Henares que, a partir de 1537, escreveu muitas comédias latinas para serem representadas pelos seus alunos nas classes de Retórica, das quais apenas se conhecem Necromanticus, Lena, Suppositi e Decepti. As primeiras três comédias são imitações de Ludovico Ariosto e a última procede de La commedia degli Ingannati do poeta italiano Alessandro Piccolomini.

Justo Garcia Soriano, na sua obra sobre o teatro universitário em Espanha, lembrava que, nos Estatutos da Universidade de Salamanca de 1538, vinha expressamente referida a obrigação de os alunos saírem em certos dias específicos para orar e para fazerem declamações públicas e que, em cada ano e em cada colégio, se deveria representar uma comédia de Plauto ou Terêncio, ou tragicomédia, havendo mesmo um prémio em dinheiro para o regente que melhor fizesse ou representasse as ditas comédias ou tragédias.

Mais recentemente, Jesús Menéndez Peláez, tratando do teatro escolar nas suas vertentes universitária e jesuítica, assinala as características tipológicas deste último, referindo-o como um teatro pedagógico, auxiliar dos Studia humanitatis, e numa dualidade cristianismo/cultura clássica. Conclui o autor que a aprendizagem e o exercício do latim, da retórica e da oratória através do teatro clássico era prática usual nas universidades e colégios espanhóis, pelo que "Las aulas de la universidad renacentista respiraban, pues, un ambiente teatral"2.

\section{Acto}

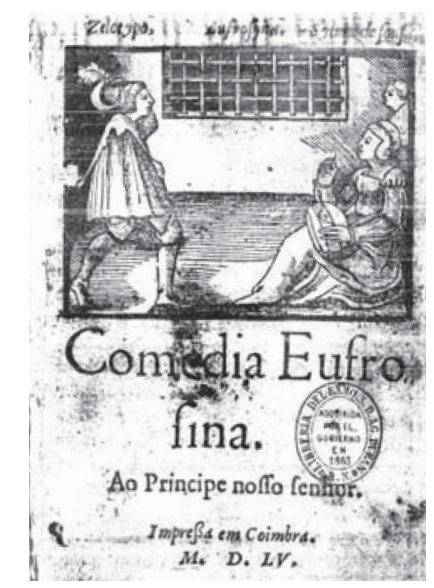

Rosto da edição Princeps da Comedia Eufrosina, 1555

\footnotetext{
1 Justo Garcia Soriano, p. 9. Infelizmente o investigador toledano não indica onde e quando ocorreu esta representação em Portugal.

2 Jesus Menéndez Peláez, p. 584.
} 
A prática destes "divertimentos dramáticos" não poderia deixar de influenciar as universidades portuguesas, neste caso, a Universidade de Coimbra, transferida para essa cidade desde 1537. Jorge Faria lembrava que Aires Barbosa "durante 20 anos professara latim e grego na Universidade de Salamanca, prestava ao rei esclarecimentos de tomo sobre os estatutos desta escola, onde os divertimentos escolares, portanto facultativos, se faziam com comédias de Plauto ou Terêncio ou com tragi-comédias escritas pelos lentes"3.

Fialho de Almeida, no seu artigo sobre récitas de estudantes em Coimbra, recorda como as representações cénicas costumavam dar brilho às datas importantes da Universidade, ou "realçar o ouro de certas datas"4, como é o caso da representação da Comedia do Fanchono de António Ferreira, por académicos, em Coimbra, aquando das festas nupciais do Príncipe D. João, no ano de $1552^{5}$.

Gustavo Matos Sequeira, em Teatro de Outros Tempos, no capítulo "Divertimentos escolares", lembra que no século XVI "[o] teatro constituía como que uma aula prática do estudo das Humanidades", um complemento da educação escolástica. Com ironia, o conhecido olissiponense refere que, a par destes "divertimentos" latinos, em Coimbra "os escolares divertiam-se, também, representando e ouvindo representar em português", pois em 1527 fora ali representada A Farça dos Almocreves e a Comédia da divisa da cidade de Coimbra de Gil Vicente, e que

Jorge Ferreira de Vasconcelos compôs, nesse período, a famosa Eufrosina onde os estudantes se caricaturam em grosso e o gentio coimbrão - escudeiros, povo, moças do rio - aparece também. ${ }^{6}$

Posteriormente, José Pinto Loureiro, falando sobre o Teatro em Coimbra e a sua História, oferece algumas informações dispersas sobre fontes e obras publicadas, textos representados em Coimbra, regras seguidas no Colégio das Artes, Estatutos e a obrigação de representações por parte dos estudantes, etc. Tratando de obras representadas, refere que,

Jorge Ferreira de Vasconcelos, nascido nos campos do Mondego (em Montemor-o-Velho), que casou nesta cidade, nela escreveu e provavelmente viu representar a sua comédia Eufrosina, cuja acção aqui decorre. ${ }^{7}$

3 JORGE FARIA, p. 261.

4 Fialho de Almeida, p. 10

${ }^{5}$ Note-se que o casamento do Príncipe D. João com a Princesa D. Joana de Áustria, filha de Carlos V e da Imperatriz D. Isabel, foi por procuração. Diz-nos Luís de Matos que "em 11 de Janeiro de 1552 o embaixador de Portugal em Espanha desposava-a em Toro, por palavras de presente". Cf. Luís de MaTOS, p. 11.

${ }^{6}$ Gustavo Matos Sequeira, p. 69. Repare-se que Gustavo Matos Sequeira segue o equívoco de Teófilo Braga quanto à datação da Comedia Eufrosina, acreditando na precedência do teatro de Ferreira de Vasconcelos em relação ao de Sá de Miranda, embora há muito os trabalhos de Carolina Michaëlis de Vasconcelos alertassem para o erro tipográfico da "Carta da Índia" e, por isso, Menéndez y Pelayo, em 1910, remetesse para uma data posterior: 1536. A divulgação da edição princeps, em 1951, viria a dar razão à insigne lusitanista, pois efectivamente aí se lê "1536".

7 José Pinto Loureiro, p. 3. 
Assinala ainda na sua Resenha de Espectáculos e outras Informações, que

... aqui foi escrita e possivelmente representada, segundo se infere da declaração do autor, a comédia Eufrosina de Jorge Ferreira de Vasconcelos. ${ }^{8}$

Hernâni Cidade recorda que, na Universidade de Coimbra, desde o ano de 1538, havia representações teatrais no Colégio de Santa Cruz, dado que "[a] Universidade portuguesa por sua vez tornou em 1546 obrigatórias essas representações, que aliás oito anos antes já se praticavam no Colégio de Santa Cruz", acrescentando ainda que pelo Estatuto de 1561 se depreende que a comédia deve ser representada em língua original ${ }^{9}$.

Segundo Américo da Costa Ramalho, a vida universitária na pequena cidade de Coimbra tinha na época uma dimensão intelectual intensa e uma expressão bem mais viva do que no nosso tempo. Em "Alguns aspectos da Vida Universitária em Coimbra nos meados do século XVI (1548-1554)", este professor coimbrão oferece-nos informações acerca da vivência cultural/ teatral na Universidade de Coimbra. A propósito destas cerimónias marcadas com representações teatrais que envolviam lentes e alunos, Costa Ramalho lembra que a tragédia Judith de Diogo de Teive, representada por esses anos, se perdeu, chegando somente até nós a Tragédia do príncipe João, escrita depois de 1554. A tradição das representações dramáticas continuou após o Colégio das Artes ter passado para as mãos dos jesuítas depois de 1555.

Eugenio Asensio admite que as duas comédias de Sá de Miranda foram representadas na Universidade de Coimbra pela alusão inscrita na dedicatória de António Ferreira na Comédia do Fanchono de $1562^{10}$. O mesmo terá acontecido com as duas comédias de António Ferreira, compostas enquanto este frequentava os estudos universitários em Coimbra: a Comédia do Fanchono ou Bristo foi escrita durante as férias de 1552 e representada na Universidade de Coimbra, segundo se lê no frontispício da edição princeps, e a Comédia do Cioso, também aí foi representada entre 1552 e $1556^{11}$.

Embora falte documentação que permita comprovar a realização de todas estas representações poderemos aceitar, tendo em conta algumas informações dispersas, que, na década de trinta do século XVI, terão sido representadas as duas comédias de Sá de Miranda, na década de quarenta, a Eufrosina de Jorge Ferreira de Vasconcelos e, na década seguinte, as duas comédias de António Ferreira.

8 José Pinto Loureiro, op. cit., p. 44.

9 Hernâni Cidade, p. 60.

10 Cf. Eugenio Asensio, Comedia Eufrosina, p. LXIII. Embora, quanto a si, a expressão de António Ferreira acerca dessa representação "onde pouco antes se viram outras que a todas as dos antigos ou levam, ou nom dam ventagem" seja suficientemente vaga. Note-se que, como já foi referido, a representação da Bristo terá acontecido no ano de 1552, aquando das festas nupciais do Príncipe D. João com a Princesa D. Joana.

11 Eugenio Asensio informa que se publicou anónima com o título Comédia do Fanchono, em Coimbra, João de Barreira, 1562. Quanto à princeps refere que está perdida, mas que se encontram dois exemplares da $2 .^{\mathrm{a}}$ edição em Madrid, edição desconhecida pelos portugueses. Cf. Eugenio Asensio, Estudios Portugueses, p. 288. 


\section{Acto}

A tese de que a Comedia Eufrosina terá sido representada prende-se com a presença de referências muito precisas que se encontram no texto acerca do local onde se desenvolve a acção da peça, bem como com a enunciação do próprio texto. No Prologo da obra, o "autor ou representador" João d'Espera Deus entra em cena. Numa atitude frontal e provocatória, interpela o público, perguntando-lhe se "há aqui algum tam pintalegrete que ousasse assi entrar despejado", declarando ainda que vem "em feyção de seruir aa scena". Através do enunciado "Quando eu pera ca parti logo fiz conta que auia de ser neste anfitrionio conuento passarinho em mão de menino" assinala o local onde ele e esse público se encontram e, numa única frase, são-nos dadas marcas de tempo, espaço e acção. De seguida, coloca toda a trama da peça a passar-se "na antiga Coimbra".

No fim do Prologo, quando a personagem pede "Agora dayme ouuidos prontos pera o que se segue", volta a criar um outro momento teatral. A ambiguidade da expressão "dayme ouuidos" pode pressupor que se trataria não de uma representação, como deduzimos pela expressão anterior "seruir aa scena", mas de uma récita, o que em concreto pode não diferir assim tanto, pois continua, em ambos os casos, a encontrar-se a presença dos elementos constituintes do teatro ${ }^{12}$.

Constata-se que Ferreira de Vasconcelos é muito preciso nas suas indicações sobre o quê, quem, quando e onde decorre a acção. A personagem está numa situação pública, dirigindo-se a uma assistência que parece responder às suas interpelações brincalhonas acompanhadas de gestos muitos específicos, em si reveladores do desempenho cénico da personagem. Só assim, na opinião de Carolina Michaëlis de Vasconcelos e, mais tarde na de Eugenio Asensio, seria possível compreender muitas das falas da figura dramática de João d'Espera Deus. Ou seja, encontra-se aqui um tipo de enunciação que revela e contempla uma série de marcas que manifestam a óbvia teatralidade do texto.

Este aspecto performativo, central na mais recente teoria teatral, foi discutido no Livro 6 da Poética. A propósito das partes ou elementos essenciais da tragédia, Aristóteles faz algumas observações acerca da configuração da Ópsis (conceito grego que se prende com a dimensão visual e da aparência das coisas), sugerindo que o espectáculo em si cria no espectador uma atracção emocional, mas que, de todas as partes constituintes da tragédia, é o que se conecta menos com a poesia dramática e o menos importante. ópsis é convencionalmente traduzido como "espectáculo" ou "encenação" e designa a dimensão espectacular do drama ${ }^{13}$.

Esses elementos essenciais assinalados por Aristóteles são terreno fértil para a teoria teatral. Outros aspectos deverão ser considerados quando se fala na perspectiva do espectáculo dramático pois, como lembra Cesare

\footnotetext{
12 Veja-se o caso dos University Wits, onde autores como Marlowe escreveram as primeiras tragédias renascentistas para jovens recitarem.

13 Aristóteles, Capítulo VI, "Definição de tragédia - Partes ou elementos essenciais", in Poética, pp. 110-114.
} 
Molinari, esse mesmo conceito de "teatralidade" deve ser usado com "consciência histórica" dado que, durante séculos, alguns dos maiores textos da história de literatura dramática (as tragédias de Ésquilo, Sófocles e Eurípides) foram considerados irrepresentáveis e, portanto, não "teatrais".

Note-se ainda a este propósito, embora sob uma perspectiva literária, a convicção de Eugenio Asensio, quando referia que o Prologo de João d'Espera Deus se compreenderia melhor se se aceitasse que "fué representado con caracterización y gesticulación apropriada"14. Para ele, encontram-se aí piadas internas, retorcidas, deliberados enigmas e, talvez até, a satirização de algum professor como era uso nas representações escolares. Uma espécie de farpas, entendidas à época pelos alunos e lentes e que hoje temos dificuldade em perceber.

\section{Acto}

As matérias e os autores referidos no texto da comédia, como se pode verificar através dos três exemplos seguintes, dizem muito acerca do mundo cultural, ético e estético do comediógrafo, das suas circunstâncias e do seu público.

A enunciação no Prologo da Comedia Eufrosina evidencia desde o início o "casamento" entre o saber popular e o erudito. Se a frase inicial proferida por João d'Espera Deus "Quem viver veraa a volta que o mundo daa" remete para o primeiro âmbito, após esta primeira nota de abertura, a personagem envereda por outros trilhos, chamando a atenção para que "Vedes, que eu sou como Jano, não me aueis de fazer esgares per detras, que vos logo não vaa co o dedo ao olho" apontando deste modo, para uma autocaracterização cómica, de raiz literária/mitológica. Jano, um dos mais antigos deuses do panteão romano que, com a dupla cara, via as burlas que lhe faziam, quer pela sua frente, quer por detrás. Jano, portador de dois rostos que se opõem, um deles olhando para a frente, outro para trás, era a metáfora teatral da sua contemporaneidade, combinando a ideia da passagem do tempo e da mudança ${ }^{15}$. A frase seguinte "Não vos acotoueleis que he muy castiço: ca diz o grego: Mais facil he reprender que imitar" indica muito significativamente com que herança cultural esta e as outras personagens vão evoluir, dramaticamente falando.

Acerca do género dramático cultivado, João d’Espera Deus assinala que "Eu sou dos que requerem Aretusa e comedia no mais maçorral estilo", reenviando-nos para os primórdios da história da comédia, que, na sua vertente mais crítica e satírica é designada como comédia ática. Uma matéria que o comediógrafo irá desenvolver no Prologo da Comedia Ulysippo, apresentado por Mercurio, e que pressupõe a existência de um auditório informado.

Jorge Ferreira de Vasconcelos introduz neste Prologo uma das preocupações dos humanistas ao tempo: a da supremacia e autonomização da

14 Eugenio Asensio, 1951, op. cit., p. LXIX.

15 Pierre Grimal refere que "Séneca conta que Jano, hábil orador, como frequentador do Fórum e mesmo na arte de ver para a frente e para trás" (isto é, examinar as questões em todos os seus aspectos). Cf. Pierre Grimal, Dicionário da Mitologia Grega e Romana, p. 259. 
língua portuguesa face ao latim. Um tema polémico, segundo a interpelação de João d'Espera Deus: "Quee isso? Espirrar? Já vos roeis as unhas", divertindo-se a brindar a assistência com uma frase em latim, propositadamente complexa, parodiada, para demonstrar que a língua portuguesa possuía "alfayas próprias" com que se podia apresentar ao mundo. A expressão "Rideuos vos" mostra a resposta do público quanto ao resultado paródico da tradução efectuada do latim para o português, uma situação que faria todo sentido num ambiente universitário ${ }^{16}$.

Podemos imaginar que a explicação em voz alta "o muyto mal se pode dizer em pouco", oferecida por este inveterado falador a uma assistência de alunos e professores, provocaria farto riso. E, porque, quanto a si, os homens fazem a linguagem, remata declarando que "E se os Portugueses se prezassem dela como das armas, leyxariam escrituras de mores façanhas que os Hebreos de incredulidades, os Gregos de fabulas, e os Latinos de deoses". Não era acanhado o desígnio de João d'Espera Deus. O comediógrafo português transforma esta personagem medieval, "estrangeyro" e "judeu errante", numa personagem que reinventa novas utilizações do saber, oferecendo, deste modo, uma curiosa dualidade que é, simultaneamente, um ponto de chegada e um ponto de partida.

O segundo exemplo compreende a estratégia quanto à conquista amorosa. Zelotypo está enamorado da bela Eufrosina, mas sente-se derrotado por contingências de classe, pois a donzela é nobre e rica. Além disso, vencer no Amor, tal como no campo de batalha, pressupõe treino e armamento apropriado. Neste caso, é o "soldado prático" do Amor, o experimentado Cariophilo, que irá ajudar com alguns expedientes o melancólico Zelotypo a montar o ataque ao castelo. As armas aqui são as palavras, até que venha o tempo propício das acções. Palavras que rolam como rio de memória, palavras de mel, doces e sedutoras, que forçam a vontade de quem as ouve e animam a coragem de quem as diz. As palavras estão estruturadas num pensamento encadeado, rigoroso, argumentativo, que faz progredir a acção. Por detrás das palavras está o exemplo, citado ou aludido. E, por detrás dos exemplos, estão os deuses, semi-deuses e heróis, convocados a preceito pelo dramaturgo para ajudarem no magnífico jogo da conquista amorosa.

Mais longe do Olimpo e mais perto dos homens, encontram-se os autores antigos, também eles convocados para este festim de invenção dramática. Para a literatura, Horácio e a sua "arte poetica"17; para a sedução, Ovídio,

16 Assinale-se que uma das tarefas a que os renascentistas se dedicaram com entusiasmo foram as chamadas artes da palavra, uma admiração que coincidiu com o surgimento das línguas neolatinas, as línguas romance, chamadas vulgares, a partir da língua latina. Em termos europeus, os homens do Renascimento são conduzidos à "questão da língua". Lorenzo Valla com as suas Elegantiae Linguae Latinae (1440) espalha uma semente por toda a Europa; as Institutiones Latinae (1481) de Nebrija e, pouco depois, a sistematização científica das novas línguas também por Nebrija (1492), para o caso espanhol, e Pietro Bembo (1525), para o caso italiano, estabelecem constantes conexões com a língua de Lácio. Em Portugal, os protagonistas desse esforço da fixação da língua portuguesa são João de Barros, Fernão Oliveira e Pero de Magalhães de Gândavo (1574), sendo que o tema da língua é igualmente abordado, como estamos a ver, no Prologo da Eufrosina, onde, aliás, vêm mencionadas todas as autoridades, de Valla a Bembo.

17 Op. cit., p. 181. 
hábil e erudito magister amoris ${ }^{18}$; para a conquista, Propércio, estratego determinado, para quem a amada é uma praça-forte a conquistar e, em cujo terreno, ou se vence ou se é vencido ${ }^{19}$. Para outros assuntos, a lista é invejável: Homero, Marco Aurélio, Séneca, Platão, e tantas outras autoridades conhecidas através das matérias árduas e doutas que os alunos estudavam, e que, agora de uma forma divertida, como compete ao género, estão ao serviço de uma comédia e de um jovem dramaturgo.

No início da fábula encontramos Zelotypo em conflito interno e crise, morrendo de amor por uma jovem dama. Depois de muita insistência e impaciência do trocista Cariophilo "desenfardelay ja os fumos desse rapaz Cupido" é que o amante zeloso se atreve, contrafeito, a nomeá-la. Na cena

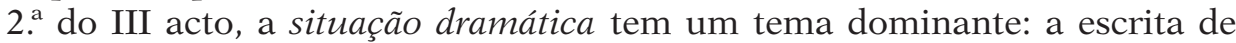
uma carta. Zelotypo, aconselhado por Cariophilo, escreve uma carta de amor para ser entregue a Eufrosina, ajudando desta forma o amigo que, segundo o seu criado, está fechado na sua "pousada" com a viola a "trouar ou estoruar". Cariophilo troça dos versos/trovas em castelhano que Zelotypo lhe apresenta, incentivando-o a escrever uma carta refinada a Eufrosina. Insistindo na aplicação dos preceitos da escrita de uma carta de amor "ha nesta materia cinco postos abalizados, ou propositos (...) Primeyramente auveis de fazer o alicesse", Cariophilo ministra-lhe todo o catálogo de regras epistolográficas, cada vez mais complicadas ${ }^{20}$. Zelotypo não se intimida: "Como se alguem reria se vos Ouuisse desses vossos preceitos e arte pastrana" 21 . Todo o jogo da escrita dos inícios das cartas, sucessivamente rejeitados pelo catedrático da matéria, até à aprovação de um, que afinal é igual aos anteriores, mostra-nos o que a teoria teatral chama de cena dramática ou alta ou cena de gradação ascendente ${ }^{22}$.

É muito engraçado ver como os preceitos gramático/epistolográficos servem tão maravilhosamente o negócio do Amor. É óbvio que a lição estava bem aprendida. É hilariante e cómico vermos o convencido Cariophilo a ministrar com autoridade doutoral os ensinamentos adquiridos na literatura antiga ao enamorado quanto atrapalhado Zelotypo. Bons leitores de "monseor Ouidio", ambos evocam a Arte de Amar: o experimentado Cariophilo afirmando "que se rij Jupiter dos perjuros amantes", enquanto o melancólico Zelotypo, que esgrima com o amigo com as mesmas armas, contrapõe-lhe com outro parágrafo do mesmo Ovídio "nem sempre Jupiter rij dos perjuros

18 Op. cit., p. 184.

19 Op. cit., p. 186.

20 Op. cit., p. 188.

21 Op. cit., p. 190.

22 A cena retrata o comportamento dos amantes. Zelotypo toca e trova, rói as unhas, estica os dedos, escreve e deita fora, etc. Esta sequência de acções, por si só, provoca o cómico, mas vê-las, e ouvir a descrição paródica do criado torna a cena ainda mais teatral. A acção decorre dentro do quarto, acção que o público vê, mas, ao ser também contada/mostrada através dos apartes zombeteiros de Andrade, permite ao autor acentuar o ridículo da situação e, desta maneira, dar a palavra ao criado, com uma série de atributos que lhe estão indexados: curiosidade dos criados e a troça crítica aos amos, o mexerico, a promiscuidade, uma situação típica da comédia de Plauto e de Terêncio. 
amantes, mas as vezes os ouve com orelha surda", perspectivas contrárias que casam maravilhosamente com o argumento da comédia ${ }^{23}$.

No terceiro exemplo, que envolve o par das donzelas, Eufrosina e Silvia de Sousa, de novo, deuses, heróis e autores antigos ajudam com os seus exemplos e a sua autoridade a justificar decisões difíceis de tomar. No início do IV acto, Silvia de Sousa num melancólico monólogo expressa a sua mágoa pela escolha do primo a favor de Eufrosina. Por outro lado, informa-nos que esta também se encontra enamorada de Zelotypo. Vemos que começa a pôr em prática o compromisso assumido com o primo de interceder por ele junto de Eufrosina e, por isso, refere estrategicamente que "Ja o amor anda por aqui". Eufrosina esquiva-se ao assunto, divagando sobre a brevidade da vida. No seu discurso, Eufrosina evoca os deuses e as mulheres da antiguidade, e todo um passado literário que tem atrás de si. Exemplos vários que irão justificar a sua resolução futura, permitindo-lhe aceitar sem culpa o amor de Zelotypo.

No monólogo seguinte, Eufrosina encontra-se numa situação de crise, de dilema, em que a personagem vai ter que optar, decidir, aceitar ou não aceitar o amor de Zelotypo. Sentindo-se vítima de forças superiores, desculpa-se, e veja-se a que exemplos recorre: "Phedra amou seu enteado: de Pasifae naceo o Minotauro. Europa amou o touro Cretense: Simiramis o seu proprio filho. Canace e Biblis amarão a seus irmãos. Mirra a seu proprio pay"24. Menos monstruoso é o seu amor por Zelotypo e, por isso, prossegue: "também Diana amou o Orião, Aurora a Cefalo. Venus a Adonis, pobres caçadores, porque entenderam que na pessoa estaa o verdadeyro merecimento...". Este último exemplo permite-lhe justificar a situação, em princípio intransponível, que é a diferença de classes entre ambos. Por fim, rendida, declara "hey de obedecer a quem todos obedecem" 25 . A donzela Eufrosina maneja com perícia exemplos das heroínas antigas, oferecidos pelas criações literárias, para conseguir advogar em causa própria. A plêiade de deuses permite-lhe ganhar coragem para enveredar por caminhos interditos na altura, escolhendo amar e casar segundo a sua vontade e gosto e, como a protagonista vicentina, acaba por dizer que "quero antes asno que me leue que caualo que me derrube" 26 .

Desculpas não faltarão a esta vencida do tirano Amor, já que por ele "quebrou Hisiphile suas leis. Medea matou seu irmão, Philis matouse por Demofom, por Hercules Dianira, e Dido por Eneas"27.

Deste modo, a convivência com os autores antigos, além de proporcionar um elevado saber e prazer estético, constituíam um desafiador exercício de inteligência. O saber literário ajudava a pensar, a discorrer, a alimentar um discurso e a construir um argumento. A agir num quadro em que a palavra era motor de acção. E hoje?

\footnotetext{
23 Op. cit., p. 154

24 Op. cit., p. 248.

25 Op. cit., pp. $248-9$.

26 Op. cit., p. 249

27 Op. cit., p. 251.
} 


\section{Acto}

Pierre Grimal salientou que o teatro antigo "não pertence só ao passado, interessa a toda a cultura ocidental". Este pressuposto pode aplicar-se ao teatro renascentista português, que faz a recepção do teatro antigo, nomeadamente aquele que estamos aqui a evocar, a produção dramática de Jorge Ferreira de Vasconcelos.

Este interesse torna-se mais evidente quando se põe este teatro em cena, pois,

Em todos os tempos, o teatro foi um meio poderoso de acção; serve de veículo a ideias e "mentalidades" que o palco propaga, difunde e impõe com uma eficácia e um alcance maiores que os do livro. ${ }^{28}$

Não deixa de ser curioso pensar que uma obra que terá nascido num ambiente universitário, num contexto de representação (caso aceitemos que a comédia foi representada em Coimbra, pelas razões atrás apontadas), possa voltar à escola e ao convívio de jovens alunos do 3 . $^{\circ}$ ciclo, e recuperar essa teatralidade original que ficou submergida pela forte componente literária, ao longo de cinco séculos ${ }^{29}$.

A necessidade de uma "visão teatral" tem que ver com a relação intrínseca entre o texto dramático e a encenação que o "interpreta", pois, como nos diz Cesare Molinari,

As tragédias de Shakespeare e os dramas de Dumas, embora possam conter uma visão teatral, só se tornam efectivamente teatro no momento em que um olhar teatral pousa neles e os assume como tema ou ponto de partida de uma realização cénica e concreta. ${ }^{30}$

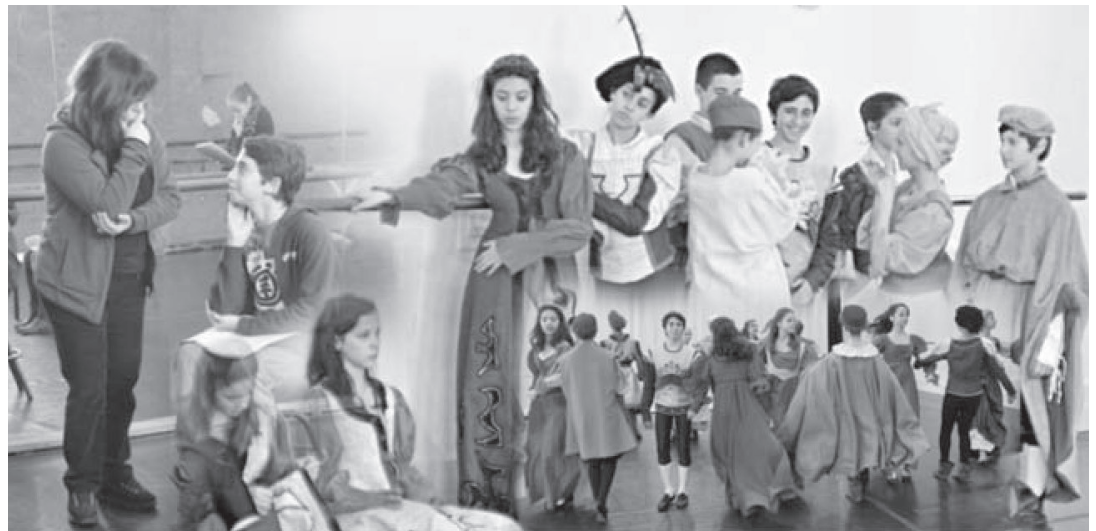

Imagens dos ensaios da Comedia Eufrosina na EDCN.

28 Pierre Grimal, $O$ Teatro Antigo, p. 9.

${ }^{29}$ Lembremos que Eugenio Asensio, no estudo que fez na edição princeps da Eufrosina, propõe os anos de 1542-1543 para a composição da obra.

30 Cesare Molinari, p. 9. 
Foi possível, através de uma dramaturgia (um processo já iniciado desde 1995, para a representação da obra no Convento dos Inglesinhos) desenvolvida na perspectiva de uma adaptação juvenil, chegar a uma versão cénica, cuidada e criteriosa, e nela redescobrir e evidenciar esses elementos teatrais, de molde a que adolescentes de 13/14 anos pudessem dar corpo e voz a estas palavras tão antigas mas reconhecidamente intemporais. Em Abril de 2011, após alguns meses de trabalho com alunos do $8 .^{\circ}$ ano, de duas escolas artísticas, a Escola Nacional do Conservatório de Dança e a Escola Nacional do Conservatório de Música, foi apresentada uma versão juvenil da Eufrosina. Embora a faixa etária fosse muito jovem, foi possível constatar que fruíram e perceberam o texto, riram com ele e que se divertiram a representá-lo ${ }^{31}$.

No programa do espectáculo foram deixadas as impressões imediatas do trabalho realizado. Uma reflexão sobre a presença dos clássicos na escola, assente numa prática concreta e não em juízos de valor a priori. Sobre esta experiência artística dizia:

As dificuldades são conhecidas: a apreensão dos conteúdos, a linguagem antiga, a exigência da leitura em voz alta, um verdadeiro Cabo das Tormentas dos tempos modernos. ${ }^{32}$

Não deixando de assinalar as virtualidades que a prática teatral oferece, já que, como se sabe,

... o teatro, através do jogo das personagens e da dramatização da acção no espaço cénico, possibilita um campo de experiência estética por onde passa a descoberta, o divertimento e a criatividade que permite ultrapassar os obstáculos de partida. ${ }^{33}$

Hoje, como no seu tempo, o texto de Vasconcelos continua actual e vivo. Ler os clássicos a partir do olhar do século XXI proporcionou, nesta experiência escolar, uma reflexão sobre a sua transmissão ancorada numa prática cénica, privilegiando áreas pedagógicas e artísticas, num contexto de educação e formação, num trabalho de cooperação entre alunos, pais e professores.

A recepção do público foi muito calorosa e entusiástica, sendo de salientar o testemunho escrito do classicista Raul Miguel Rosado Fernandes, que se inicia com uma interrogação "Terá sido abandonado ou mal interpretado o que chegou até nós do teatro português?" 34 . Também o ensaísta e crítico de arte José Augusto França escreveu que "Vi do alto desenvolverem-se, em suspiros, ternuras e esperanças, os amores de Eufrosina" 35 .

31 Foi também assim com os actores e o público, aquando da representação da Comedia Eufrosina na Igreja do Convento dos Inglesinhos (1995), com a Comedia Ulysippo no Teatro da Trindade (1997), e nas leituras encenadas com a Comedia Aulegrafia na Bulhosa (2006) e no Teatro Nacional (2009).

32 Silvina Pereira, p. 2

33 Op. cit., p. 2.

34 Carta manuscrita de Raul Miguel Rosado Fernandes.

35 Carta manuscrita de José Augusto França. 


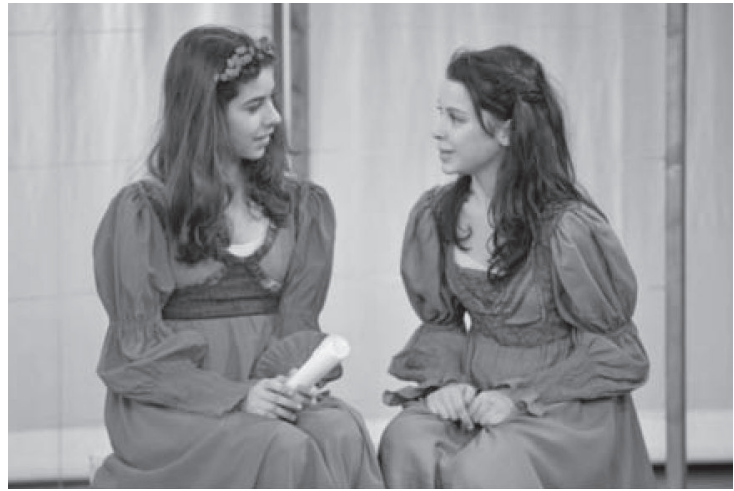

Silvia de Sousa e Eufrosina.

Tudo isto nos leva a pensar que esta prática de pôr em cena em contexto escolar o teatro clássico português é dar vida ao nosso teatro. Incluir no repertório teatral nacional uma comédia luminosa, solar, com final feliz, é redimensionar a nossa participação na História Teatral Europeia, mostrando que, em Portugal, houve, nesse campo, uma linha de continuidade, e não de ruptura, com o que de melhor se fazia na época a nível de produção. Não se trata de preencher um vazio entre Gil Vicente e Almeida Garrett, trata-se de rever um olhar enviesado sobre o teatro português e o seu lugar na dramaturgia mundial.

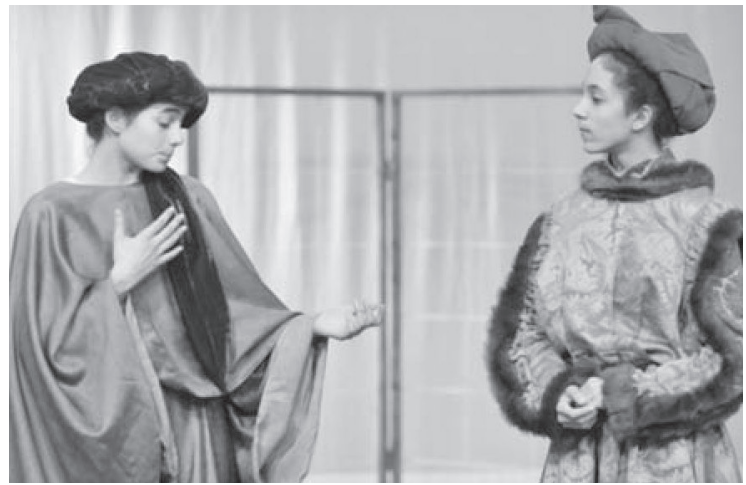

Philotimo e Dom Carlos.

\section{Epílogo}

Se a primeira obra dramática de Jorge Ferreira de Vasconcelos visou, ao tempo, uma encenação para ser feita e vista por estudantes, então ter apresentado a Comedia Eufrosina na escola quase cinco séculos depois constituiu, de certa forma, o reatar de uma tradição. Representar a comédia de Vasconcelos foi uma lição de cultura clássica, lição de arte e de vida, evidenciando que os clássicos sempre apostaram na ideia de que um artista deve educar o público, não apenas na dimensão ética, mas também estética. 
Ontem, como hoje, esse saber continua a falar-nos aos ouvidos e aos olhos, aos sentidos e à alma. Como refere Roger-Pol Droit, eles são "um passado presente, uma escola de vida, aberta e livre onde podemos tentar aprender a reinventar o futuro" 36 .

Como compete à comédia, esta foi uma história com um final feliz.

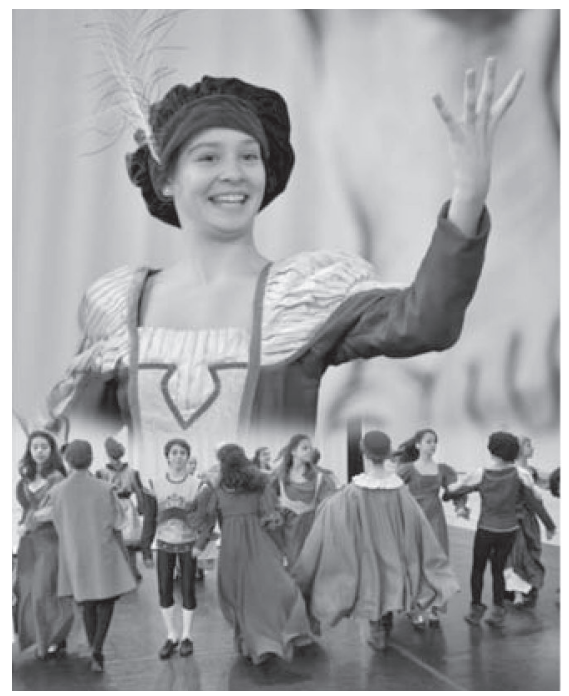

Dança final do espectáculo.

Vos valete et plaudite

\section{BIBLIOGRAFIA}

Almeida, J. Fialho DE, "Em Coimbra - Récitas de Estudantes", in À Esquina, 2. a ed. Porto, Clássica Editora, 1960.

ARISTóteles, Poética, Tradução, prefácio, introdução, comentário e apêndices de Eudoro de Sousa, Lisboa, Imprensa Nacional-Casa da Moeda, 1986.

Asensio, Eugenio (edição, prólogo e notas), Comedia Eufrosina de Jorge Ferreira de Vasconcelos, texto de la edicion principe de 1555 con las variantes de 1561 y 1566, Madrid, CSIC - Instituto Miguel de Cervantes, 1951

—- Estudios Portugueses, Paris, F. C. Gulbenkian/Centro Cultural Português, 1974.

Cidade, Hernâni, Luís de Camões. Os Autos e o Teatro do seu Tempo, Lisboa, Livraria Bertrand, 1956.

Droit, Roger-Pol, Voltar a Ler os Clássicos, Lisboa, Temas e Debates, Círculo de Leitores, 2011.

FARIA, Jorge, “O Teatro escolar dos séculos XVI, XVII e XVIII”, in A evolução e o espírito do teatro em Portugal, 1. vol., Lisboa, ed. O Século, 1947.

36 Roger-Pol Droit, p. 31. 
García SoRIANo, Justo, El teatro universitario y humanístico en España - Estudios sobre el origen de nuestro arte dramático: con documentos, textos inéditos y un catálogo de antiguas comedias escolares, Toledo, 1945.

Grimal, Pierre, Dicionário da Mitologia Grega e Romana, coordenação de VICTOR JABOUILlE, Lisboa, Difel, 1982.

—, O Teatro Antigo, Lisboa, Edições 70, 1986.

Loureiro, José Pinto, O Teatro em Coimbra - Elementos para a sua História, Coimbra, Edição da Câmara Municipal, [1959]/1964.

Matos, Luís DE (Introdução), Sentenças para a ensinança e doutrina do Príncipe D. Sebastião de André Rodrigues de Évora, Fac-símile do manuscrito inédito da Casa de Cadaval, Lisboa, edição do Banco Pinto \& Sotto Mayor.

Menéndez Peláez, Jesús, "El teatro escolar latino-castellano en el siglo XVI", in Historia del Teatro Español (dirección de Javier Huerta Calvo), Madrid, Editorial Gredos, 2003.

Molinari, Cesare, História do Teatro, Lisboa, Edições 70, 2010.

Pereira, Silvina, Programa do espectáculo Comedia Eufrosina de Jorge Ferreira de Vasconcelos, versão juvenil e encenação de Silvina Pereira, Escola de Dança do Conservatório Nacional, Lisboa, 2011.

Ramalho, Américo da Costa, "Alguns aspectos da vida Universitária de Coimbra nos meados do séc. XVI (1548-1554)", Para a História do Humanismo em Portugal, vol. I, Coimbra, INIC, 1988.

Sequeira, Gustavo Matos, Teatro de outros tempos, Elementos para a História do Teatro Português, Lisboa, 1933.

ABSTRACT: The article refers to theatrical representations in universities and colleges, including the University of Coimbra, mentioning specifically the triangle consisting of Sá de Miranda, Jorge Ferreira de Vasconcelos and Antonio Ferreira. From the Comedy Euphrosyne of Jorge Ferreira de Vasconcelos, it also intended to make a reflection about the presence of the classics today, allowing the resumption of a theatrical tradition, in school and at University. The experience of staging of a juvenile version of Euphrosyne showed that this is a dramaturgy exemplarily alive and that has much to say to our contemporaneity.

Key words: Comedia Eufrosina; Jorge Ferreira de Vasconcelos; Scholar tradition; Portuguese classical theatre; spectacle. 